\title{
Arabic Translation from Bait Al-Hikma to Toledo School of Translators: Key Players, Theorization and Major Strategies
}

Omar EL GHAZI ${ }^{*}$ \& Chakib BNINI ${ }^{2}$

${ }^{1}$ Department of English Studies, Faculty of Arts and Humanities Ben M'sik, Hassan II University of Casablanca, Morocco ${ }^{2}$ Department of English Studies, Faculty of Arts and Humanities Ben M'sik, Hassan II University of Casablanca, Morocco Corresponding Author: Omar EL GHAZI, E-mail: omar.elghaziuh2c@gmail.com

ARTICLE INFO
Article History
Received: August 05, 2020
Accepted: September 21, 2020
Volume: 3
Issue: 9
DOI: $10.32996 /$ ijllt.2020.3.9.7

KEYWORDS

Al-Andalus, Baghdad, Bait AlHikma, Free Translation, Literal Translation, Strategies, Source Text, Target Text, Toledo School of Translators

\section{ABSTRACT}

Throughout history, Arab scholars have produced a number of important works in different fields, which helped boost human civilization. This was achieved thanks to the utmost efforts made by a panel of prominent translators working in Bait Al-Hikma (Lit. House of Wisdom) in Baghdad. These translators transmitted Greek, Persian and Indian works into Arabic during the 'Golden Arabic Era of translation' which goes back to the Abbassid Caliphate (750 CE- $1258 \mathrm{CE}$ ). Likewise, translation movement in Al-Andalus took its systematic and intensive shape at the beginning of 12th century CE with the establishment of Toledo School of Translators in the city of Toledo. However, translations produced in Al-Andalus were chiefly rendered from Arabic into Latin and Old Spanish, mainly by non-Arab translators. The present paper explores the schools of translation in Baghdad and Toledo and the main strategies or methods used by each of these schools. This overview will demonstrate the importance of taking into consideration Arabs' translation theorization in line with western theories of translation. The paper also reveals that Arab translators were not mere transmitters of Greek philosophy and ancient knowledge, but great thinkers who adapted Greek, Indian and Persian ideas to their own thought.

\section{Introduction}

Historically, Arabs did not live in isolation from other neighboring nations, including the Persians, the Turks, the Romans, among others. Contact was not confined to their neighbors, but also reached other geographically remote nations, such as India and China, with which Arabs established 'diplomatic' and more importantly commercial relations. The Arabs' commercial activity contributed to the expansion of the scope of communication and intercultural contact with other nations, as is clearly shown in the contents of both Arabic and foreign literatures and cultures. This is clearly indicated by the undeniable number of foreign words in both Arabs' and the neighboring nations' lexicon. This reciprocal contact reached its level of maturity thanks to the translation works from Arabic into the other respective languages and vice versa.

Although it may be contested that translation has always existed as human beings needed to communicate with other people and nations speaking languages different from theirs, the discipline studying translation is relatively recent; the growth of translation studies as an autonomous discipline is a success story of the 1970 s and 1980 s.

As the main objective of this paper is to investigate major translation scholars and strategies employed by those translators in the Abbassid and Andalusian eras, the focus will be on written rather than on oral translation, because 'translation' is usually understood to operate in this mode (the latter is commonly known as interpreting or interpretation).

K C AL-KINDI CENTER

$\mathbf{R}$ D FOR RESEARCH AND DEVELOPMEN Your gateway to world-class research
Published by Al-KindiCenter for Research and Development. Copyright (c) the author(s). This is an open access article under CC BY license (https://creativecommons.org/licenses/by/4.0/) 


\section{Arabs' definition of translation}

Looking up the word 'translation' in English dictionaries reveals that this word has the meaning of 'transporting, conveying, transforming, etc.' For instance, all the definitions provided by Collins Online Dictionary incorporate the meaning of movement and transformation. In mathematics, as an example, it is defined as "a transformation in which the origin of a coordinate system is moved to another position so that each axis retains the same direction or, equivalently, a figure or curve is moved so that it retains the same orientation to the axes". In finance and accounting, translation is seen as "the act of converting one currency into another" (Collins Cobuild Dictionary, 2020). The word 'translating', in the sense of transformation and transfer is also employed by the Business Dictionary, where the word 'innovation' is defined as "The process of translating an idea or invention into a good or service that creates value or for which customers will pay" (Business Dictionary, 2020).

In other languages, however, the word translation may suggest additional or even quite different meanings; e.g. in Arabic, besides its common meaning, the word 'tarjamah' (ترجمة) also means 'biography'. The Arabs have different ways of expressing the idea of translation; the word 'naql' (نَقْ) or transmission, as a case in point, often interchangeable with the word 'ترجمة', means the transfer of a text from one language into another; it involves translation in both directions. The words 'taarib' (تعريب) and 'taajim' (تعجي), in contrast, refer only to translation into one direction. The word 'taarib' means the translation of a text from a given language into Arabic, whereas the word 'taajim' indicates the translation of a text from Arabic into another language.

Another word which derives from the verb 'tarjama' (تَرجَم), meaning to translate, is the Arabic word 'turjuman' (ترجمان). It is defined by Lisan Al-Arab online dictionary as:

$$
\text { " الترجمان هو الذي يترجم الكلام أي ينقله من لغة إلى لغة أخرى، و الجمع التراجم “ }
$$

Turjuman (Interpreter) is the person who translates utterances; that is, he or she transmits them from one language into another. Its plural is Tarajem (Interpreters, my translation).

This meaning is also expressed by the great Arab poet Abu Al-Tayyib Al-Mutanabbi in his famous poem which starts with the following verse: “....

$$
\text { تجمع فيه كل لِلسن وأمة **** فما تفهم الحُداثَ إلا التراجم }
$$

In this verse, the poet describes the army of Sayf Al-Dawla Al-Hamdani in the battle of 'Al-Hadath' between the Hamdanids and the Byzantine Empire. The Hamdanid army was composed of different nations speaking different languages. This made communication in that multiracial and multilingual army difficult, but thanks to interpreters, the soldiers could understand each other.

Another meaning provided by Al-Raid Online Dictionary is 'explanation' and 'interpretation'. This meaning is found in the famous story of Abdullah ibn Abbas, a Companion of Prophet Mohamed (PBUH), in which the Prophet supplicated Allah for him saying: "اللهم فقهه في الدين و علمه التأويل" ("O Allah! Endow him with the favor of comprehending religious knowledge and teach him interpretation.") (Al-Hakim et al.). Following this supplication, Ibn Abbas was widely known among Muslims as 'the Learned Master of the Ummah and the Interpreter of the Quran' (حبر الأمة وترجمان القرآن).

\section{Foundation of House of Wisdom: A Historical background}

Arabs showed great interest in translation since the dawn of Islam, as can be understood from the letters sent by Prophet Mohamed (PBUH) to kings and rulers beyond Arabia. Some of these rulers were not Arabs, such as the Vicegerent of Egypt (Al-Muqawqas), Chosroes/ Khosrow of Persia (Kisra) and Caesar of Rome (Hercules). During the era of the four caliphs, the process of spreading Islam in various lands outside the borders of Arabia necessitated translation. The process of translation, however, was first known to impose itself during the rule of the Umayyads, when the fifth caliph Abdelmalek ibn Marwan (d. 705 CE / 86 AH) ordered the arabisation of administration known then as 'taarib al- dawawin' (تعريب الدو اوين).

Translation activity reached its zenith under the Abbasid caliphate (750 CE - $1258 \mathrm{CE}$ ), particularly during the reign of AlMa'mun (813-33 CE), known as the Golden Era of translation. Al-Ma'mun promoted the most important institute of higher 
learning in Islam, which also became the most celebrated center of translation in Arab history. Bait Al-Hikma or Dar Al-Hikma (House of Wisdom) in Baghdad, founded by Haroun Al-Rashid, functioned as an academy, library and translation 'workshop'.

A more detailed account of the translation activity between Arabic and foreign languages is provided in the following section. This account can be explored in the light of the three stages: the Prophetic era, the Umayyad caliphate and the Abbasid caliphate.

\subsection{Translation in the Prophetic era}

There are many indications that the era of the Prophet Mohamed (PBUH) witnessed a translation activity, especially with the necessity of spreading the Message of Islam beyond Arabia. According to Hussam Eddine Mustapha (2013) some narrations indicate that Salman Al-Farisi, the Prophet's Companion, was thought to be the first to translate the meanings of Surat AlFatiha (the Opening) during the prophetic era. He further indicates that the Companion Zaid ibn Thabit, who was fluent in the Syriac, Persian and Greek languages, became famous as the first translator in Islam, and that he was in charge of correspondence as commissioned by the Prophet. The same author also mentions that there was an ancient garment (بُردة) dating back to $643 \mathrm{CE} / 22 \mathrm{AH}$ containing a three-line text in Greek with translation in Arabic bearing the name of the Companion Amr ibn Al-'Aas.

\subsection{Translation in the Umayyad era}

Despite the interest of the Umayyads in conquests and in the expansion of their country, their interest in translation was of equal importance, as they regarded translation as a key means to achieve strength and flourish. The Umayyads translated into Arabic the most important books of sciences from Latin and Greek, and books of medicine, astronomy, chemistry and architecture from Syriac. Among the important translation figures of the Umayyad dynasty, was the Prince Khalid ibn Yazid (d. $704 \mathrm{CE} / 85 \mathrm{AH}$ ) who ordered scholars from Egypt to translate into Arabic the alchemy, medicine and astronomy works of Greek and Coptic authors. Another famous translator during the Umayyad rule was the Syriac Jacob of Edessa (d. 708 CE/89 $\mathrm{AH}$ ) who translated many books from Greek into Arabic.

\subsection{Translation in the Abbasid era}

Translation became very active after the Abbasids came to power in Iraq following a victorious revolution in $750 \mathrm{CE} / 132 \mathrm{AH}$ against the Umayyad Caliphs. Under the authority of Al-Mansour, the second Caliph, the new capital moved from Damascus to Baghdad, at a time when Muslim conquests and imperial growth were beginning to foster a dynamic cultural climate. Different intellectual traditions became united under Muslim rule, including Greek learning from Europe and Alexandria, as well as that of the Persians, Indians, Syriac and Sumerians in the East.

The history of translation movement during the Abbasid rule can be subcategorized into three stages; the first stage describes the first steps towards the foundation of Bait Al-Hikma, the second stage is about translation movement in the 'Golden era of Arabs' translation' during Al- Ma'mun's rule and the third stage concerns the beginnings of the decline of translation movement under the Abbasids.

\subsubsection{The first stage}

This stage started from the establishment of the Abbasid state until the death of the sixth Caliph, Al-Amine (from $750 \mathrm{CE} / 132$ $\mathrm{AH}$ to $813 \mathrm{CE} / 198 \mathrm{AH}$ ). during this period, translation began to flourish because it was officially patronized by the Abbasid caliphs who encouraged translators. In contrast, translation activity in the Umayyads' period was only cared for by individuals. Two Abbasid caliphs can be mentioned in this phase: The second caliph Abou Jaafar Al-Mansour and the fifth caliph Haroun Al-Rashid.

\subsubsection{Abou Jaafar Al-Mansur}

Al-Mansur (d. 775 CE /158 AH) encouraged translating works from Greek and Persian into Arabic. Among the translated works during his reign was the book "Calilah and Dimnah" (كليلة ودمنة) which constituted one of the beginnings of fictional literature among the Arabs. Said Al-Andalusi in "Tabaqat Al-Umam" as quoted from Bsoul (2019) writes: 
The book Kitab Kalilah wa Dimnah brought by the Persian wise Burzuwayh from India to the king of the Persians Khosrow I. It was translated from Sanskrit to Persian, and it was translated by Abdallah ibn al-Muqaffa from Persian into Arabic. It is a book of great interest, purposeful, and beneficent. (p. 82)

The Greek works that were translated into Arabic during the reign of al-Mansour include those of Aristotle, 'the Almagest' of Ptolemy, Euclid's 'Elements', and 'the Great astronomical tables of the Sindhind' (لكيج السند هند الكبير), which was an Indian astronomical handbook with tables used to calculate celestial positions. This book was translated by a panel of scholars such as Mohamed Ibrahim Al-Fazari, Habash ibn Abdellah Al-Baghdadi, Mohamed ibn Moussa Al-Khawarizmi, Ibn Al-Adami, and others (Bsoul, 2019).

Besides this translation movement, this era started strongly lean towards 'ulum al-kalam' or 'books of theology' (علوم الكلام) and Greek logic which initiated the spread of the doctrine of the Mu'tazila (المعتزلة).

\subsubsection{Haroun Al-Rashid}

Al-Rashid (d. $809 \mathrm{CE} / 193 \mathrm{AH}$ ) was interested in translation, and brought translators from Lebanon, Egypt and Syria who were fluent at least in one foreign language besides Arabic, whether they were Muslims or non-Muslims. Although its founder is a controversial issue, some historians argue that Al-Rashid was the real founder of Bait Al-Hikma in Baghdad, while others claim that its founder was his son Al-Ma'mun. However, I am rather inclined to believe that the real founder of Bait Al-Hikma was Haroun Al-Rashid under the names of Dar Al-Hikma (House of Wisdom) or Khizanat Al-Hikma (Storehouse of Wisdom). Equipped with books transported from Asia Minor (modern Turkey and Armenia), this 'house' or 'storehouse' was later on promoted by Al-Ma'mun.

As far as Al-Rashid's caliphate is concerned, it is worth to mention the role of the Barmaki family in the flourish of translation activity. Al-Rashid's minister Yahya ibn Khalid Al-Barmaki (d. 806 CE/ 190 AH) played a significant role in translation movement by bringing Greek books to Baghdad, spreading them amongst Bait Al-Hikma's translators in order to render them into Arabic.

Within this regard, the literary critic and historian Dr. Shawqi Daif as quoted from Bsoul (2019) reports:

The Barmakis encourage scholars to translate all the precious materials into Arabic from Persian and Greek, had been translated before their time, so that they would be more accurate and more precise as Yahyā ibn Khālid did with the book of Almagest of Ptolemy (p. 94).

Ibn Al-Nadim as quoted from Bsoul (2019) indicates that the Barmakis were responsible for appropriating the scientific heritage of India into the Abbasid state. They attracted medical scholars from India. During the reign of Al-Rashid, some Greek works were re-translated such as Ptolemy's 'Almagest'.

\subsubsection{The second stage}

The second stage started from the beginning of Al-Ma'mun's rule ( $813 \mathrm{CE} / 198 \mathrm{AH}$ ) until the beginning of the rule of the tenth Caliph Al-Mutawakkil (847 CE/ 232AH). The House of Wisdom's main project was collecting and translating numerous works from the Greek literary canon, which established an enormous influence on Arab thought. Works including those by Plato, Aristotle, Ptolemy, Hippocrates and Euclid were requested from Western libraries, such as that of Constantinople, and brought back to Baghdad for translation. Under Caliph Al-Ma'mun, Bait Al-Hikma was greatly extended to include separate galleries for each branch of science.

\subsubsection{The third stage}

The third stage started from the beginning of Al-Mutawakkil's rule (847 CE/ 232AH) until the end of the Abbasid caliphate (1258 CE/ 656 AH). Translation flourished under Al-Ma'mun and considerably declined under the reign of Al-Mutawakkil (847$861 \mathrm{CE}$ ), who endorsed a more literal interpretation of the Quran and Hadith, and discouraged the spread of Greek philosophy. In $1258 \mathrm{CE}$, the accomplishments of the House of Wisdom and the Islamic Golden Age were brought to a cruel end. During the Mongol invasion of Baghdad under Hulagu, grandson of Genghis Khan, the mosques, libraries, homes and hospitals of this great city were all destroyed. The family of the last Abbasid Caliph Al-Mustaasim, as well as thousands of the city's inhabitants, were slaughtered, and the collection of books and manuscripts stored at the House of Wisdom were thrown into the Tigris. It 
is reported that for days afterwards, the river ran black with the ink of books, and red with the blood of scholars and other slaughtered people.

\subsection{Major translators in the Abbasid era}

Translation movement flourished in the Abbasid Caliphate, especially during Al-Ma'mun's rule. Describing this movement, Abou Rayyan in Bsoul (2019) writes:

In the period (198-300), the translation movement flourished, scientific activity increased, books were translated in all the sciences, ethics, philosophy and psychology, and at this stage, astronomy, medicine, logic and philosophy were transferred. In astronomy, Almagest by Ptolemy was translated, and in medicine Hippocrates and Galen, and in logic, Aristotle's books, as well as the books of metaphysics. Some of Plato's dialogues and Galen's whole work on the dialogues and some of Plato's political books were translated (p. 101).

Among the famous translators during the Abbasid Caliphate, we can cite the following figures who practiced mostly at Bait Al-Hikma. It is worth mentioning that the list is not exhaustive, otherwise, there were many other prominent translators who contributed to the flourish of translation movement in the 'Golden Age'. The translators are presented in an ascending order according to their date of decease.

Youhanna ibn Al-Batriq (d. $815 \mathrm{CE} / 200 \mathrm{AH}$ ), also known as Youhanna Al-Turjuman (the Translator Jonah son of the Patriarch), ibn Al-Batriq was a Syrian scholar who pioneered the translation of ancient Greek texts into Arabic. He was an early major figure in the transmission of the Classics at the closure of Late Antiquity. He translated for Caliph Al-Mansur the major medical works of Galen and Hippocrates. He also translated 'the Secret of Secrets' which was claimed to be translated from Greek into Syriac and later on, from Syriac into Arabic.

Al-Ḥajjaj ibn Yousef ibn Mațar (d. $833 \mathrm{CE} / 218 \mathrm{AH}$ ) was a mathematician and translator. According to Brentjes in William et al. (2007), he was one of the most influential translators of the late 8th and early 9th centuries in Baghdad (the capital of the Abbasid Empire). Ibn Matar translated Ptolemy's 'Megále Sýntaxis' (later known as the Almagest) and Euclid's 'Elements'. In the early $9^{\text {th }}$ century, he translated the Elements, apparently on the basis of a single Greek manuscript, into Arabic for Yahya ibn Khalid Al-Barmaki (d. 805 CE/ 189 AH), the Vizier (Minister) of Caliph Haroun Al-Rashid. This translation was revised by Ibn Matar for Al-Ma'mun (r. $813 \mathrm{CE}-833 \mathrm{CE}$ ). The version in question was described as more sophisticated than his first original translation.

Ibn Naima Al-Himsi (d. 835 CE/ 220 AH) was a Syrian Christian who transmitted Greek works into Arabic. In particular, AlHimsi translated Aristotle's 'Sophistical Refutations' and Physics into Arabic. Endress as quoted in Adamson (2017) shows that the Arabic version of Plotinus 'Theology of Aristotle' was produced by Al-Himsi. Its preface begins with the following excerpt:

The first chapter of the book of Aristotle the philosopher, called in Greek 'Theologia', that is, 'discourse on divinity'. The exposition of Porphyry of Syria, translated into Arabic by Ibn Na'ima al-Himsi, and corrected for Ahmad ibn al-Mu'tasim by alKindi.

According to Al-Safadi, Al-Himsi's approach to translation, as will be discussed later on, was based on a strict literal method, i.e. each Greek word being translated by its Arabic equivalent.

Al-Abbas ibn Said Al-Jawhari (d. $860 \mathrm{CE} / 245 \mathrm{AH}$ ) was a geometer and astronomer who worked at the House of Wisdom in Baghdad. According to Marvin Bolt in Calvo (2007), Al-Jawhari made solar, lunar, and planetary observations in Baghdad from $829 \mathrm{CE}$ to $830 \mathrm{CE}$ and was charged by Al-Ma'mun with the task of providing appropriate instruments for the year-long series of astronomical observations in $832 \mathrm{CE}-833 \mathrm{CE}$ in Damascus. His most important work was his 'Commentary on Euclid's Elements' which contained nearly fifty additional propositions and an attempted proof of the parallel postulate. The 'Commentary' was listed in the 'Fihrist' (Index), a work compiled by the bookseller Ibn Al-Nadim in 988 CE (O'Connor and Robertson, 1999).

Abu Yousuf Yaaqoub Al-Kindi (d. $873 \mathrm{CE} / 259 \mathrm{AH}$ ) was a renowned translator, physician, philosopher, mathematician, geometer, logician, and astronomer. He worked with a group of translators who translated works of Aristotle, the Neo- 
Platonists, and Greek mathematicians and scientists into Arabic (Adamson, 2020). He was appointed by a number of Abbasid Caliphs to oversee the translation of Greek scientific and philosophical texts into Arabic.

Hunayn ibn Ishaq (d. $873 \mathrm{CE} / 260 \mathrm{AH}$ ) is known in the West by the Latinized name "Joannitius" and referred by some scholars as "Sheikh of translators". Hunayn mastered the four principal languages of his era: Greek, Syriac, Persian, and Arabic. He is credited with an immense number of translations, ranging from works on medicine, philosophy, astronomy, and mathematics, to magic, and oneiromancy ${ }^{2}$. It is reported that the Caliph used to give him the equivalent weight in gold to that of the books he translated from Greek and Syriac into Arabic.

It should not be thought that the Arabs who were translating these Greek texts simply sat down with a pile of Greek manuscripts and translated them. Most of the difficulty occurred in searching for the manuscripts which were to be translated. In order to find manuscripts of the works of Aristotle and others, Al-Ma'mun sent a team of his most learned men to Byzantium. It is thought that Hunayn ibn Ishaq, being more skilled in the Greek language than any of the other scholars in Baghdad, was on this expedition (O'Connor and Robertson, 1999).

An example of the lengths that Hunayn ibn Ishaq endured in order to find a particular manuscript is his description of a search for a medical manuscript cited by Iskandar and Shehaby as quoted from O'Connor and Robertson (1999) in their online archive $^{3}$ : "I sought for [the manuscript] earnestly and travelled in search of it in the lands of Mesopotamia [in modern Iraq], Syria, Palestine and Egypt, until I reached Alexandria, but I was not able to find anything, except about half of it at Damascus".

Thabit ibn Qurra (d. $901 \mathrm{CE} / 288 \mathrm{AH}$ ) was a translator, mathematician, physician and astronomer known as 'Euclid of the Arabs'. Ibn Qurra excelled in Syriac, Greek and Arabic. He translated from Greek into Arabic works by Apollonius, Archimedes, Euclid and Ptolemy. He also revised the translation of Euclid's Elements previously translated by his Master Hunayn ibn Ishaq and rewrote Hunayn's translation of Ptolemy's 'Almagest' and translated Ptolemy's 'Geography'.

Ishaq ibn Hunayn (d. $910 \mathrm{CE} / 297 \mathrm{AH}$ ) was one of the most important translators of Greek scientific and mathematical works into Arabic. Like his father Hunayn (Master of translators), Ishaq was a physician but he understood mathematics and astronomy in order to be able to grasp the sophisticated arguments of Euclid's 'Elements' and Ptolemy's 'Almagest', both of which he translated from Greek into Arabic. These two works, which were of immense importance for the subsequent development of Greek mathematical astronomy into the Islamic world, were Ishaq's primary contribution to astronomy. Ibn Hunayn translated a number of other works from Greek, such as Euclid's 'Optics', 'the Spherics of Menelaus', 'On the Moving Sphere' by Autolycus, in addition to several Platonic dialogues and works of Aristotle, including 'On the Soul and the Physics' (Cooper in Fazlıoğlu et al., 2007).

Qusta ibn Luqa (d. 912 CE/ 299 AH) was a Christian physician, philosopher and astronomer active in the second half of the ninth century CE. He was born in Baalbek in Lebanon, spent the middle part of his life in Baghdad, and then travelled to Armenia, where he died (Hogendijk, 2008). Ibn Luqa translated medical and astronomical works from Greek into Arabic. In addition, he composed and translated mathematical and philosophical works. Ibn Luqa's scholarly reputation extended far and wide and was noted for his scientific achievements (especially in medicine, where his authority surpassed Hunayn ibn Ishaq according to the bibliographer ibn Al-Nadim (d. 990 CE / 370 AH) as cited in Hockey (2007). He reportedly collected Greek scientific manuscripts from Byzantine lands; his translations and revisions formed an important part of his scholarly activities. Ibn Luqa was fluent in Greek, Syriac and Arabic in which he produced many original scientific compositions.

\subsection{Translation Methods used by Bait Al-Hikma's translators}

According to Al-Safadi in Al-Amili's 'Kashkul', two methods of translation were adopted by Bait Al-Hikma translators; the first method was associated with Youhanna ibn Al-Batriq and ibn Naima Al-Himsi. This method was word-for-word and consisted of translating each Greek word with an equivalent Arabic word, but when there is no equivalent, the Greek word is adopted.

\footnotetext{
2 Divination by the interpretation of dreams (Collins online dictionary).

${ }^{3}$ The MacTutor History of Mathematics archive is a website maintained by John J. O'Connor and Edmund F. Robertson and hosted by the University of St Andrews in Scotland. It contains detailed biographies on many historical and contemporary mathematicians, as well as information on famous curves and various topics in the history of mathematics.
} 
This method, as in all literal translations, was not successful so that many of their translations were later revised by Hunayn ibn Ishaq with whom the second method was associated, which exercised translating sense-for-sense.

Because of the utmost importance of Al-Safadi's categorization of translation methods used by the Arab translators in the 'Golden Age', the full text is provided below in Arabic (Source Text) with its translation in English conducted by Rosenthal in Christidis (2007). My additions in the English versions are included in square brackets:

\begin{tabular}{|c|c|}
\hline Rosental's translation & Al-Safadi's source text \\
\hline $\begin{array}{l}\text { Al-Salah Al-Safadi as quoted in Al-Amili's Al- Kashkul writes: } \\
\text { The translators use two methods of translation: [the first method } \\
\text { is associated with Youhanna ibn Al-Batriq, Ibn Naima Al-Himsi } \\
\text { and others.] According to [this method], the translator studies } \\
\text { each individual Greek word and its meaning, chooses an Arabic } \\
\text { word of corresponding meaning and uses it. Then he turns to the } \\
\text { next word and proceeds in the same manner until in the end he } \\
\text { has rendered into Arabic the text he wishes to translate. This } \\
\text { method is bad for two reasons. First, it is impossible to find } \\
\text { Arabic expressions corresponding to all Greek words and, } \\
\text { therefore, through this method many Greek words remain } \\
\text { untranslated. Second, certain syntactical combinations in one } \\
\text { language do not always necessarily correspond to similar } \\
\text { combinations in the other; besides, the use of metaphors, which } \\
\text { are frequent in every language, causes additional mistakes. } \\
\text { The second method is that of Hunayn ibn Ishaq, al-Jawhari and } \\
\text { others. Here the translator considers a whole sentence, } \\
\text { ascertains its full meaning and then expresses it in Arabic with a } \\
\text { sentence identical in meaning, without concern for the } \\
\text { correspondence of individual words. This method is superior, } \\
\text { and hence there is no need to improve the works of Hunain ibn } \\
\text { Ishaq [except for books of mathematics in which he was not } \\
\text { expert. As for those of medicine, logic, natural sciences, } \\
\text { theology, the books he had translated did not need refinement. } \\
\text { He also revised the translation of Euclid's Elements and rewrote } \\
\text { Hunayn's translation of Ptolemy's Almagest and translated } \\
\text { Ptolemy's Geography.] (pp. 941-942) }\end{array}$ & 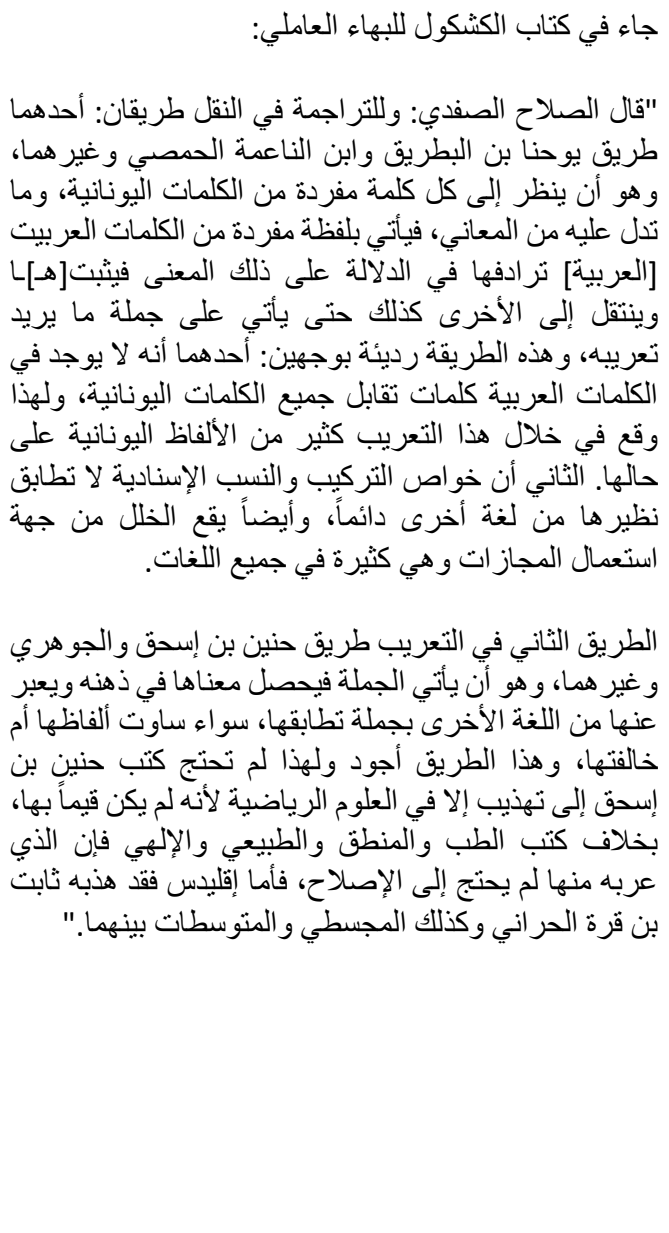 \\
\hline
\end{tabular}

Commenting on the two texts above, it is worth stressing that the source text is originally written by Salah Eddine Al-Safadi (d. $1363 \mathrm{CE} / 764 \mathrm{AH}$ ) and its translation is conducted by Professor Franz Rosenthal. It is crucial to emphasize this fact, because a number of scholars have mentioned (Rosenthal) the translator while disregarding the original writer (Al-Safadi), as in Baker \& Saldanha (2009, p. 333) and Munday (2001/2016, p. 36). The non-specialist may misleadingly think that Rosenthal is the original writer, although Rosenthal $(2005$, p. 17) himself has referred to the original writer showing that the two methods of translation are found in the book 'Al-Ghaith Al-Musajjam' (الغيث المسجم في شرح لامية العجم) written by Al-Safadi and quoted by AlAmili in his book 'Al-Kashkul' (الكثكول لخاتمة الأدباء وكعبة الظرفاء).

The dichotomy 'literal' vs. 'free' described by Al-Safadi constitutes one of the major issues debated throughout history starting from Cicero in the first century (d. 43 BC) to Al-Jahid (d. 869 CE) who argues in Baker (2001) that the translator can never do the original author justice or express him with fidelity, and finally to a number of modern translation scholars and linguists such as Vinay and Darbelnet (1958) who classify translation procedures into direct (or literal) and oblique (or free). 
Ibn Al-Nadim as quoted in Bsoul (2019) strengthens Al-Safadi's description of the methods used by Greco-Arabic translators. He observes that the approach to translation followed by the majority of translators such as Hunayn ibn Ishaq, al-Jawhari, Thabit ibn Qurra, Qusta ibn Luqa, and al-Kindi is based on reading the sentence or chapter and understanding the correct meaning, which is then expressed in clear and concise Arabic. The supporters of this method were known for their honesty, knowledge, integrity, and ethics. They mastered the subjects they translated along with both the source and target languages.

Al-Safadi also highlights an important phenomenon of specialization in translating different types of texts. In his 'quality assessment' of the translated texts, giving the example of the then 'Master of translators' or 'Sheikh of translators', he stresses that the field of specialty plays a significant role in the quality of the product. Accordingly, the translator excels when he or she translates within his or her subject area.

On the other hand, the specialization in translation during the 'Golden Age' can also be noticed in the language pairs used at that time. Prominent translators from Greek included Hunayn ibn Ishaq, his son Ishaq ibn Hunayn, Thabit ibn Qurra, Yaakoub ibn Ishaq Al-Kindi, etc. Translators of Persian works included Abdullah ibn Al-Mouqaffaa, Abou Hafs Omar ibn Al-Farkhan and Sahl ibn Haroun, etc. From Syriac, we can mention Hunayn ibn Ishaq, his son Ishaq ibn Hunayn and his nephew Houbaysh ibn Al-Hassan Al-Aasam, etc.

\section{Translation movement in Al-Andalus}

It is accepted that civilization is a common edifice built by humanity, and every developed nation has contributed to this universal heritage. Like Baghdad and Damascus in the East, Al-Andalus ${ }^{4}$ in the West was considered as a center of Islamic philosophy where a number of important scholars in many areas such as medicine, mathematics, astronomy, history, geography, biography, philosophy, poetry and theology.

The Greek, Persian and Indian works translated in the East especially in the Abbasid era as stated above, were re-translated, completed or commented on by a number of Andalusian scholars and scientists, to name just a few, the physician, surgeon and chemist Abou Al-Qasim Az-Zahrawi, Latinized as Albucasis (d. $1013 \mathrm{CE} / 403 \mathrm{AH}$ ), the physician, surgeon and poet Abou Marwan Abdelmalek ibn Abi Al-Alaa Ibn Zohr, Latinized as Avenzoar (d. 1162 CE/ 557 AH), the novelist, philosopher, theologian, physician and astronomer Abou Bakr Mohamed ibn Abd Al-Malik ibn Mohamad Ibn Tofail, also known as Avetophail (d. $1185 \mathrm{CE} / 580 \mathrm{AH}$ ), the philosopher, theologist, physician, jurist and scholar Abou Al-Walid Mohamad Ibn Ahmad Ibn Roshd, widely known as Averroes (d. $1198 \mathrm{CE} / 594 \mathrm{AH}$ ), the pharmacist, botanist, physician and scientist Abdellah ibn Ahmad Al-Malaqi, commonly known as Ibn Al-Baitar (d. 1248 CE/ 645 AH), etc. These scholars made great contributions to the Andalusian culture and to the development of its civilization and later on to the European Renaissance. In this regard, Robert Briffault as quoted in Bsoul (2019) observes:

It is very likely that if it were not the Arabs, the emergence of modern European civilization never appeared, but it is certain that without them, Europe would not have been in such a position, which enabled it to outperform all previous roles. For if there is not one view of European progress that cannot inevitably trace the influence of Islamic culture, this influence is not clearer and more important elsewhere, but in the composition of that force, which constitutes the main characteristic of the present world and the most important source of its victory, Nature "'and' spirit of science". What we now call science, which emerged in Europe as a result of the spirit of investigation, the new methods of research, the methods of experimentation, observation and measurement, and the emergence of mathematical sciences, was in a real state unknown to Greece. That spirit and those methods have been introduced into the European world by the Arabs (pp. 207-208).

The Arab-Muslim 'Empire' possessed translations of Aristotle, Plato's works, a large part of Galen's work, Euclid's 'Elements', Ptolemy's 'Almagest' as well as other Greek scientific works. Al-Andalus was at that time home to numerous centers of learning in Toledo, Cordoba, Seville and Granada. With the capture of Toledo by the Christians in (1085 CE) and later on Cordoba (1236 CE) Seville (1248 CE) and Granada (1492 CE), Toledo was the center of translation movement in Spain, attracting a flock of scholars to translate various Arabic works, including important contributions from classical Europe preserved through the earlier Abbasid translation movement.

\footnotetext{
${ }^{4}$ The name Al-Andalus or Andalusia is accepted to be derived from the name "Vandalacia" referring to the Vandals that reached Gibraltar in 411 BC by migrating from North to South. This term was used by Muslims after their conquest of Andalusia. (Arslan, 1997)
} 
It is worth mentioning that translation movement in Al-Andalus took its systematic and intensive shape in the beginning of the $12^{\text {th }}$ century CE with the establishment of Toledo School of Translators in Toledo. Translation activity, however, started by the Umayyad Caliph in Al-Andalus Al-Hakam Al-Mostansir (d. 976 CE/ 366 AH) who established a very rich palace library in Cordoba. This caliphal library incorporated books transported from the East, and namely from the centers of Baghdad, Damascus, Cairo, Alexandria and Constantinople.

According to Norman (History of Information, n.d.), Al-Mostansir was fond of books and learning. It is claimed that he amassed a vast library that may possibly contained over 400,000 books. During his reign, a massive translation effort was undertaken, and many books were translated from Latin and Greek into Arabic. In order to make this project successful, he constituted a joint committee composed of Muslims scholars from Arab and Amazigh communities in addition to Andalusian Mozarabs ${ }^{5}$.

\subsection{Toledo School of Translators}

Toledo was one of the most important Islamic capital cities after the Islamic conquest of Al-Andalus. It reached its peak during Islamic rule, especially during the rule of the Petty Kingdoms widely known as Muluk Al-Twaif (ملوك كو الطو ائف). These kingdoms were built on the ruins of the Umayyad State. In the first half of the eleventh CE / fifth century AH, Toledo was ruled by a powerful family called Banu di-Noun (بنو ذي النون). This Amazigh family, originating from Hawwara in the region of Souss (Morocco), established their ascendancy through military victories, and gained importance in the fields of education and culture. It became one of the major centers of Islamic culture in Al-Andalus.

After the fall of the city of Toledo to the Christians in $1085 \mathrm{CE} / 487 \mathrm{AH}$, this city became part of the Kingdom of Castile and was inhabited by a mixture of Spanish Christians, Jews, and Muslims. It became a scientific center with valuable libraries, thanks to scientists' passion. Like Bait Al-Hikma, the establishment of Toledo School of Translators had undergone three stages which can be summarized as follows:

\subsubsection{The first stage}

According to Shikha (2019), the first stage of the foundation of Toledo School of Translators started in 1125 CE / 519 AH when the head of the Archbishopric of Toledo, the monk Raymond of Toledo, appointed scholars, and particularly John of Seville (d. $1180 \mathrm{CE} / 575 \mathrm{AH}$ ) who was one of the main translators from Arabic into Castilian in partnership with Dominicus Gundissalinus (d. $1190 \mathrm{CE} / 586 \mathrm{AH}$ ), to translate most of the Arab-Islamic heritage. From that time on, the School of Translators of Toledo began its activities of translating from Arabic into Latin. This activity was mainly oriented towards scholarly translation of medical, astrological and philosophical works.

\subsubsection{The second stage}

The second stage began with the arrival of the Italian translator Gerard of Cremona (d. $1187 \mathrm{CE} / 583 \mathrm{AH}$ ) to Toledo in $1167 \mathrm{CE}$ in search of Ptolemy's Almagest which was considered one of his most famous translations from Arabic into Latin. He translated about eighty books in collaboration with Muslim scholars and Mozarabs in addition to the English Philosopher Alfred of Sarashel (CE $12^{\text {th }}$ century) (also known as Alfred the Philosopher and Alfred the Englishman) and the English translator, philosopher and astronomer Daniel of Morley (d. $1210 \mathrm{CE} / 606 \mathrm{AH}$ ) who travelled to Toledo.

\subsubsection{The third stage}

The third stage in the history of Toledo School of Translators began in the middle of the $13^{\text {th }} \mathrm{CE} / 7^{\text {th }} \mathrm{AH}$ centuries, starting from the reign of the King of Castile and Leon Alfonso X (d. 1284 CE/ 683 AH). On account of his great interest in science and translation, he was granted the epithet of 'Alfonso the Wise', or 'the Learned', and in Spanish 'Alfonso el Sabio' (Encyclopedia Britannica). The most prominent translator of this stage is the Rabbi of the Synagogue of Toledo Yehuda ben Moshe (13th century CE) who was the personal physician of King Alfonso X of Castile (Yehuda Ben Moshe - Wikiwand, n.d.)

Being an active scholar in the field of translation, King Alfonso X founded an Institute of Oriental Studies in $1250 \mathrm{CE} / 648 \mathrm{AH}$ with the aim of fostering the learning of Arabic and Hebrew in order to benefit from the Islamic heritage. In a similar move,

\footnotetext{
${ }^{5}$ Mozarab, Spanish Mozárabe, (from Arabic مستعرب, "arabicized"), any of the Spanish Christians living under Muslim rule (8th-11th century), who, while unconverted to Islam, adopted Arabic language and culture (Encyclopaedia Britannica).
} 
he established a school for mathematics and astronomy in Murcia, and nominated the Muslim scholar Abou Bakr Mohamed ibn Ahmed Al-Ruquti as head of the school. Angel Gonzalez Palencia as quoted in Bsoul (2019) writes:

Muhammad ibn Ahmad al-Ruquti was a prominent scholar in mathematics from the seventh/thirteenth century, from Ruquta in the province of Valencia. He became the head of the first Islamic school established by Alfonso X in Murcia in 667/1269. Muslim, Christian, and Jewish students came to the school to study under him. (p.147)

This school gained fame on account of this scholar to such an extent that it became a center attracting students from different parts of Europe to learn logic, mathematics, astronomy and music.

Bsoul (2019) notices that one of the advantages of this stage is the abundance of translations from Arabic to the medieval Castilian language which gave birth to modern Spanish, thanks to the personal support and patronage provided by 'the Wise King' who had the aim of making the Castilian 'language' equal to Latin by encouraging translations from Arabic into Castilian, whereas in the previous stages, the translation was mostly conducted from Arabic into Latin.

\subsection{Major translation figures of Toledo School of Translators:}

Andalusian translators played an unprecedented role in conveying Islamic heritage into Latin language. Throughout its stages of creation, Toledo School of Translators consisted of a network of translators from different religions and backgrounds who undertook the task of translating the treasures of Arabic and Islamic heritage into European languages. As reported by Santoyo in García-Izquierdo and Monzó (2012),

The Toledo School consisted of a group of translators who worked from different regions in the peninsula, mainly northern regions, under the patronage of the King [Alfonso X]. Thus, the first generation of Iberian translators dates from the twelfth century. It was composed of about ten translators who worked from five different geographical areas; more specifically, the early Toledo School was composed of an early translator, Johannes Hispalensis [John of Seville], who worked from the region of ALimia in Galicia before moving to Toledo; two translators who worked from Barcelona; one translator working from Tarazona; two translators working from an imprecise location near the River Ebro; and a small group composed of three or four translators who worked in Toledo. (p.193)

This description of the multi-ethnic 'human resources' of Toledo School of Translators provided by Santoyo did not mention the names of the translators except for the great translator John of Seville. Moreover, he disregards, on the one hand, the role of Muslim, Mozarab, Christian and Jewish translators and scholars who provided a significant contribution to the school of translators in Toledo in particular and the Andalusian translation movement in general, and on the other hand those prominent translators who came from remote parts of Europe. Within this context, Abattouy in Al-Rodhan (2012) details the provenance of the famous translators who worked at Toledo School of Translators, such as Gerard of Cremona and Plato of Tivoli who came from Italy, Adelard of Bath, Robert of Ketton and Daniel of Morley from England, Rudolph of Bruges from the Low Countries (modern Belgium, the Netherlands, and Luxembourg), and Hermann of Carinthia from the Alps. However, one can be sceptical about the translations produced by the mentioned translators who did not know Arabic language, or to be more precise, only few of them actually knew Arabic.

To dismantle this ambiguity, Abattouy in Al-Rodhan (2019) points out that a key role was played by mediators and, in particular, by Jewish scholars, who either cooperated with the Christian scholars or produced translations into Hebrew. Scholars such as Abraham bar Hiyya (d. 1136 CE/ 530 AH), Petrus Alfonsi (d. 1140 CE/ 534 AH), Judah Halevi (d. 1141 CE/ 535 AH), Abraham ibn Ezra (d. 1167 CE/ 562 AH), Abraham ibn Daud or Avendauth (d. 1180 CE/ 576 AH), etc. were familiar with the Arabic and the Latin worlds and mastered Arabic as well as a language accessible to the Latin scholars, whether Hebrew, Latin, or Castilian. But, presumably, Muslim scholars and translators who remained in the Andalus after the fall of the majority of its cities for the benefit of the Christians, together with the Mozarabs, collaborated with those translators as mediators and facilitators. This idea is supported by Abattouy as quoted in Al-Rodhan (2019) who writes:

Several translators also cooperated with Arabic assistants. For instance, Robert of Ketton and Hermann of Carinthia worked with a certain Muhammad, while Gerard of Cremona was supported by a certain Gallipus (Ghalib?) in his translation of the Almagest. The Arabic-Latin translation movement was hence, just like the Greek-Arabic translation movement, characterized by intercultural cooperation, in this case involving Christian, Jewish, and Muslim scholars. (p.178) 
On his side, Pym (1994, p.10) maintains that the translators Hermann of Carinthia (Hermannus Dalmata) and Robert of Ketton (Robertus Ketenensis) were commissioned to carry out the first Latin translation of the Quran in $1143 \mathrm{CE} / 538 \mathrm{AH}$, while a subsequent translation was conducted around $1210 \mathrm{CE} / 606 \mathrm{AH}$ by Mark of Toledo (d. $1216 \mathrm{CE} / 612 \mathrm{AH}$ ). Hermann and Robert were assisted by a native informant anonymously named 'Mahumeth' (Muhammad in Abattouy's words). The name 'Mahumeth' or 'Muhammad' suggests that this informant was a Mozarab. All the same, Pym indicates that 'Galippus' was a Mozarab who is also said to 'interpret' Ptolemy's Almagest in Romance ${ }^{6}$ language, while Girardus wrote it down in Latin. Indeed, the fact that Galippus' real name was 'Ghalib' (غالب) is highly probable as tacitly argued by Abattouy (2012).

Having displayed the role played by Andalusian translators, scientists and scholars from Muslim, Mozarab, and Jewish communities in the flourish of the translation movement in Al-Andalus and the spread of the treasures and heritage of Islamic knowledge throughout Europe, we will shed light on some of the most famous translators in Al-Andalus and particularly in Toledo School of Translators in the $12^{\text {th }}$ and $13^{\text {th }}$ centuries.

Adelard of Bath (d. $1152 \mathrm{CE} / 556 \mathrm{AH}$ ), also known as Adelardus Bathensis and Adelardus de Bada was an English philosopher and translator of Arabic scientific knowledge. He translated into Latin an Arabic version of Euclid's 'Elements', which for centuries served as the chief geometry textbook in the West. He studied and taught in France and travelled to Italy, Cilicia, Syria, and Palestine before returning to Bath in England. His 'Quaestiones naturals' (Questions on Natural Science) composed of 76 discussions on human nature, meteorology, astronomy, botany and zoology are based on Arabic science. His other writings include works on the abacus, the astrolabe, a translation of astronomical tables of Al-Khwarizmi, etc. (Encyclopedia Britannica).

Robert of Ketton, known in Latin as Robertus Ketenensis (d. 1160 CE / 555 AH) was an English astronomer, translator, priest and diplomat. He translated several works from Arabic into Latin, including the first translation of the Quran into Latin which was at the same time the first translation of the Quran into a foreign language. The translation is thought to be carried out in $1143 \mathrm{CE} / 537 \mathrm{AH}$ or $1141 \mathrm{CE} / 535 \mathrm{AH}$ at the encouragement and patronage of the Catholic Church and under the guidance of Peter the Venerable, the abbot of the Monastery of Clung (Goldstein in Bsoul 2019 and Akasoy in Lagerlund 2011).

According to Pym (1994), Robert of Ketton collaborated with Hermannus Dalmata (d. 1160 CE/ 555 AH); he further extended the team to include the Mozarab clerk Petrus Toletanus and his own notary Petrus, to make sure the text came out as acceptable Latin. A native informant anonymously named 'Mahumeth' had also been employed, but the abbot seems to have mentioned this only some years later. This further demonstrates 'the inferiorization of intermediaries' (p.10).

However, Kritzeck argues in Pym (1994) that the translators' strategic interests were quite different, since Robertus, who did the bulk of the work, actually described the job as a 'digression' from his true interests in mathematics and astronomy (p.11).

Robert of Ketton translated other works including Al-Khwarizmi's work on algebra (Hobson in Al-Rodhan 2012) and the Apologia of Al-Kindi (a tenth-century Christian, not to be confused with the Muslim philosopher of the ninth century mentioned above) (Akasoy in Lagerlund 2011: 93).

Herman of Carinthia (d. 1160 CE / 555 AH), also nicknamed Hermannus Dalmata ("the Dalmatian"), was an Austrian philosopher, astronomer, astrologer, mathematician and translator. He carried out together with his fellow Robert of Ketton the first translation of the Quran along with several explanatory documents.

Hermann of Carinthia translated several books, notably 'Kitab Islah Al-Majriti' which was published in Latin within the book of 'Kitab al-Hayah al-Șaghir'. He also translated the commentary of Abou Al-Qasim Maslama Al-Majriti (d. 1007 CE/ 398 AH) الدخل 'النظام البطليموسي' explaining Ptolemy's geocentric system (Bsoul, 2019:151), the astronomical work of Abou Maashar 'الكبير إلى علم أحكام النجوم 'Introduction to Astronomy) and the astronomical tables of Al-Khwarizmi.

\footnotetext{
${ }^{6}$ According to Posner and Sala (2019), the name Romance suggests the ultimate connection of these languages with Rome (Roman Empire). Romance languages are groups of related languages derived from Vulgar Latin within historical times and forming a subgroup of the Italic branch of the Indo-European language family. The major languages of the family include French, Italian, Spanish, Portuguese, and Romanian, etc. Romance languages share a good proportion of basic vocabulary and a number of similar grammatical forms in spite of some phonological changes.
} 
John of Seville (d. 1180 CE/ 575 AH), also called Youhanna Al-Ishbili (الانشبيلي يوحنا), Johannes Hispalensis, Johannes Hispaniensis and John of Spain, was one of the main translators from Arabic into Castilian working in partnership with Dominicus Gundissalinus, also known as Domingo Gondisalvi (d. $1190 \mathrm{CE} / 586 \mathrm{AH}$ ), during the early days of the Toledo School of Translators. John of Seville was supported by the archbishop of Toledo Raymond de Sauvetâ, also known as Raimondo or Raymond of Toledo (d. $1152 \mathrm{CE} / 547 \mathrm{AH}$ ), to translate works of astronomy and astrology, natural sciences, philosophy and logic. Among his translations, as quoted from Bsoul (2019), Pym, (1994), Abattouy (2012) and Akasoy (2011), the following works are cited, for the sake of exemplification:

- The book of arithmetic by Mohamed ibn Moussa Al-Khawarizmi (d. 850 CE / 235 AH);

- Separate treatises on the astrology and astronomy by the Persian Jewish scholar Mashallah ibn Athari (d. 815 CE/ 199 AH);

- The book 'الحركات السماوية وجو امع علم النجوم' by Ahmad ibn Muhammad ibn Kathir Al-Farghani (d. 861 CE/ 247 AH);

- The works of the Persian Muslim Astrologer Abou Maachar Jaafar ibn Mohamed Al-Balkhi (d. 886 CE/ 272 AH);

- The book 'Azzij' (الزيج) written by the Arab astronomer, astrologer, and mathematician Mohamed ibn Jaber ibn Sinan Al-Battani (d. $929 \mathrm{CE} / 317 \mathrm{AH}$ );

- The work of the Syrian physician, philosopher, astronomer, mathematician and translator Qusta ibn Luqa (d. 912 CE 299 AH) 'On the Difference between the Spirit and the Soul' for Raymond, the archbishop of Toledo.

All the above works were translated between 1130 CE-1181 CE with the assistance of Domingo Gondisalvi who was considered one of the most famous European translators of the middle Ages (Bsoul, 2019, p. 170).

Gerard of Cremona, also known as Gerardus Cremonensis (d. 1187 CE/583 AH) was an Italian translator. He travelled around 1140 CE from northern Italy to Spain in search of Ptolemy's Almagest, which he had learnt about, but had been unable to locate elsewhere. He found a copy in Toledo and learnt Arabic in order to translate it into Latin (Abattouy in Al-Rodhan 2011: 170). He produced an astonishing number of books, around 80 books, including works on astronomy, mathematics, optics, natural philosophy, and medicine. He translated, inter alia, Al-Zahrawi's 'medical encyclopaedia', Ibn Al-Haytham's 'Book of Optics', Al-Kindi's 'treatise on geometrical optics' and Al-Razi's 'a Study and Classification of Salts and Alums (sulphates)'. AlKhwarizmi's 'Algebra' (early ninth century), Ibn Sina's ${ }^{10}$ 'Canon of Medicine', 'introduction to astronomy' by Al-Farghani, translated under the title 'Liber de aggregationibus scientiae stellarum.' (Abattouy 2012, Bsoul 2019, Pym 1994)

\subsection{Major translation figures of Toledo School of Translators:}

As stated above, translation out of Arabic in Al-Andalus flourished greatly, particularly in Toledo during the 12th and 13th centuries CE. Translators of the Iberian Peninsula including those who worked in Toledo School of Translators and in other centers such as Cordoba Seville, Granada, Kingdom of Aragon, etc. were divided into two categories: the first category is acquainted with Arabic language such as John of Seville and Domingo Gondisalvi and other Jewish translators mentioned above. Those translators rendered books and treatises directly from Arabic into Latin, whereas the second category did not master and some of them were illiterate in Arabic language, especially those who travelled from Italy, England, France or the Low Countries such as Gerard of Cremona, Adelard of Bath, Robert of Ketton, etc. Those translators relied mainly on Arab, Jewish and Mozarab intermediaries who used to translate from Arabic into Castilian or Romance and then into Latin. Pym (1994) claims that the use of an intermediary Romance language would complicate the task of the translator, "since it is difficult to translate word-for-word when a Romance word stands between the Arabic and Latin" (p. 8). The task became more complicated when the Arabic word is itself a translation from Syriac which was in turn a translation from Greek as we have already seen with a number of Bait Al-Hikma translators.

Unlike Bait Al-Hikma translators who were classified as to translation methods into two camps; a camp using literal or wordfor-word translation and another opting for free or sense-for-sense translation, the translators of the Iberian Peninsula in

\footnotetext{
${ }^{7}$ Hasan Ibn al-Haytham (d.1040) was an Arab mathematician, astronomer, and physicist. He is referred to as "the father of modern optics".

${ }^{8}$ Abou Bakr Ahmed ibn Zakaria Al-Razi known in the West as Rhazes or Rasis (d. 932 CE/ 320 AH), He was a Persian physician, alchemist, philosopher, and important figure in the history of medicine.

${ }^{9}$ Mohamed ibn Mousa Al-Kawarizmi (850 CE/ 235 AH) known as Algorithmi was a Persian mathematician, astronomer, and geographer.

${ }^{10}$ Abou Ali Abdellah ibn Sina (d. 1037 CE/ 428 AH), often known in the west as Avicenna or Avicenne, was a Persian physician, astronomer, thinker and writer referred to as the father of early modern medicine.
} 
general and the translators of Toledo School in particular employed literal translation according to a number of scholars interested in Medieval translation movement, such as Kunitzsch in Pym (1994), Charles Burnett, Anna Akasoy and Mauro Zonta in Lagerlund (2011), Mohammed Abattouy in Al-Rodhan (2012) and Anthony Pym (1994).

Kunitzsch, as quoted in Pym (1994), argues that the basic translation procedure for scientific texts in the twelfth century CE was word-for-word literalism. He describes this strategy as 'slavish', since "it presents the translator as an inferiorized intermediary, subordinate to the source text" (p. 7). In the same vein, Abattouy argues that translators often "resorted to literal word-for-word replacement from Arabic into Latin, which resulted in nonsensical sentences and mangled meanings" (p.171). That is why, "the more literal translation of the Quran that Mark of Toledo completed in around 1210 CE had far less influence, [unlike the translation conducted by] Robert of Ketton which was printed for the first time in 1543 CE", as argued by Akasoy in Lagerlund (2011, p. 93).

Other examples of such method include the literal and word-for-word translation used by John of Seville in his later astrological renditions from Arabic in which he was "following the Arabic sentence structure and word order" (Thorndike: 1959, p. 26), translations of Adelard of Bath from Arabic described by Burnett in Lagerlund (2011) as "literal and technical in nature: they teach one how to compute on the abacus ${ }^{11}$, to solve geometrical theorems, to chart the course of the stars, to draw up horoscopes and to make talismans for effecting magic" (p. 26), a translation of Al-Farabi's philosophical works from Arabic into Latin around 1175 CE by Gerard of Cremona, namely 'the Enumeration of the Sciences', and a summary of books V-VIII of Aristotle's Physics described by Zonta in Lagerlund (2011) as 'faithful and literal', whereas other Farabian works were translated into Latin in a less literal way, particularly 'the Enumeration of the Sciences' which was "re-written" by Dominicus Gundissalinus in his 'De scientiis' (p. 352).

However, Abattouy in Al-Rodhan (2012) claims that Gerard of Cremona had "a good command of the languages and a clear understanding of the subject matter that he was able to produce translations that were true to the original meaning and nuances of the Arabic works" (p. 171). This very idea is expressed by Pym (1994) who writes:

Girardus Cremonensis [Gerard of Cremona] often added literal versions of transliterated terms, as well as variants found in the source manuscripts and notes designed to complete or explain the text (Clagett 1964: I 232-233, Kunitzsch 1974: 110-111, Jacquart 1989: 111-12). When in doubt, he was prepared to apply literalism twice (giving variants) or to provide marginal explanations. The effect was to elaborate on the translation without contradicting the authority of the most literal version, which was included in the translation proper (p. 9).

Nonetheless, one can wonder why the translators of Toledo School recourse to such literalism; was it because they were unable to produce sense-for-sense translations, or was it deliberately chosen for other hidden agendas or as a 'Trojan horse' in Pym's words?

In an attempt to approach this issue, d'Alverny in Pym $(1994$, p. 8) observes that literalism was used as a strategy to invent entire target-language vocabularies because a number of translators such as "Plato Tiburnensis [Plato of Tivoli) (d. $1145 \mathrm{CE} /$ $539 \mathrm{AH})$ ] and Girardus Cremonensis [Gerard of Cremona] complained about the inferiority of Latin as a language of science". Moreover, the author adds that this strategy "had been taken over from the church and should at least have looked respectable in the eyes of the church. After all, it socially restricted knowledge of science in the same way as it had restrained critical knowledge of sacred texts" (p. 8).

Ilona Opelt in Pym (1994) provides some examples of these strategies as in the example of Gerard of Cremona's 'third stage Aristotle' in which "there are references to the perfection of the Trinity, to hell, and to God as creator, where the Greek text certainly did not make such references." (p. 8). A similar example is provided by Richard Lemay in Pym (1994) who claims that “in Johannes Hispanensis's first-stage Abu Ma'shar, we find omission of the Virgin Mary described as a ('ganija' [غناج or or ]) [meaning 'a woman who behaves in a way that is intended to attract men'], omission of the sun as the giver of life, and a general attenuation of sexual references and astral fatalism [according to which everything depends on the stars] (p. 8). These modifications are suggested to be carried out in the interests of a higher authority (the Church). Daniel of Morley, in his turn,

\footnotetext{
${ }^{11}$ An abacus is a calculating instrument that uses beads that slide along a series of wires or rods set in a frame to represent the decimal places. It is the ancestor of the modern digital calculator. Used by merchants in the Middle Ages throughout Europe and the Arabic world, it was gradually replaced by arithmetic based on Hindu-Arabic numerals (Merriam Webster Dictionary).
} 
"had a certain interest in describing literally what he saw, passing the task of interpretation on to later readers" (Pym: 1994, p. 8).

But Zonta in Lagerlund (2011) seems to have another opinion remarking that

In Spain, France, and Italy a number of medieval Jewish philosophers, working in the period 1150-1500, show to have known Aristotle's thought and doctrine. In reality, most of them approached Aristotelian philosophy via Arabic paraphrases and summaries of Aristotle; they particularly employed those by Averroes, where Aristotle's original words were not literally reproduced, but "interpreted" and adapted by the Arabic philosopher to his own thought (p. 432).

This observation supports what has already been said about the sense-for-sense translation method used by Arab translators who were not mere transmitters of the Greek philosophy and ancient knowledge, but great thinkers who adapted Greek, Indian and Persian ideas to their own thought. The method consisted in understanding the content and expressing it in clear and concise Arabic. It also reveals that Arab translators mastered the subjects they translated, along with both the source and target languages and cultures.

\section{Conclusion}

Translation theory is important indeed, if not necessary, for translation practitioners. However, this theory should not be confined to Western theories which approach translation from a certain point of view, but it should be extended to Arabic, Indian, Chinese and Latin theorizations.

One who explores Arabic theorization would easily notice how rich it is. The prominent translators and scholars of Bait AlHikma produced a number of important works in favor of human civilization in general, and translation studies in particular. An example of the notions indirectly introduced is 'specialized translation' with a number of translators such as Hunayn ibn Ishaq and his son Ishaq ibn Hunayn, Al-Jawhari, Thabit ibn Qurra, Qusta ibn Luqa and al-Kindi who excelled in specific subject matters. Another crucial notion highlighted by Bait Al-Hikma translators is their definition of the dichotomy 'literal vs. free' or 'word-for-word vs. sense-for-sense' which is has enriched the field of translation studies.

On the other hand, Al-Andalus was a center of multilingual culture and had prior importance as a center of translation. Numerous classical works of Greek philosophers, such as Aristotle, Hippocrates, Galen, Ptolemy, that had been translated into Arabic during the Islamic Golden Age in Baghdad were well known in Al-Andalus, as well as the works of ancient philosophers and scientists from Persia, India, and China. This enabled Arabic-speaking populations in Al-Andalus to learn about many ancient classical disciplines that were inaccessible for them before the translation movement in the Iberian Peninsula.

The Toledan translation movement considerably contributed to the promotion of a revised version of the Castilian language which had streamlined its syntax in order to be understood by people from all walks of life and to reach lay people. The translations made by the translators of Toledo school, mainly under the tutelage and direction of Alfonso X (the wise man), established the foundations of the modern supranational Spanish language.

To sum up, Bait Al-Hikma and Toledo translators contributed to the construction of modern civilization by revitalizing ancient sciences and philosophy from Greek, Persia, India and China. Those translators were not mere transmitters but, more importantly, skilled polymath scientists whose knowledge spanned a significant number of subjects. These contributions, either from Arabic into other languages or vice versa, should be the subject of intensive study and analysis to further decipher the main methods and techniques used by each translator.

\section{About the Authors}

Mr. Omar EL GHAZI, PhD student at the Department of English Studies, Faculty of Arts and Humanities of Ben M'sik, Hassan II University of Casablanca. He graduated from King Fahd School of Translation in Tangiers. His research interests are in legal translation between Arabic, French \& English and the translation of minority languages (Tamazight as a case). He is Head of the Department of Cooperation and Partnerships at Hassan II University of Casablanca.

Dr. Chakib BNINI received his Master's degree in Descriptive and Applied Linguistics from Essex University, UK, in 1985, before obtaining his PhD degree in Translation Studies from Heriot-Watt University, UK. He is currently a Professor of Translation 
Studies and Linguistics at the Faculty of Arts and Humanities of Hassan II University, Morocco, where he is also an active member within the Centre of Doctoral Studies. His areas of academic interest include translation studies, cultural studies and linguistics.

\section{References}

[1] Al-Amili, B. (n.d.). Toroq al-Tarjamh. Kitab Al-Kashkoul. Al Maktaba al-Shamila al-Haditha. Retrieved 19 July 2020, from https://almaktaba.org/book/1571/292

[2] Al- Hakim al-Nisapuri, Ahmad Ibn Hanbal, Ibn Hibban (2011, January 12). Takhrij Hadith Allahumma faqqiho fi al-Dine wa Allimho alTaawil. Islamweb. Retrieved 19 July 2020, from https://www.islamweb.net/ar/fatwa/146975/

[3] Adamson, P. (2017). The Theology of Aristotle. In E. N. Zalta (Ed.), The Stanford Encyclopedia of Philosophy (Summer 2017). Metaphysics Research Lab, Stanford University. https://plato.stanford.edu/archives/sum2017/entriesheology-aristotle/

[4] Adamson, P. (2020). Al-Kindi. In E. N. Zalta (Ed.), The Stanford Encyclopedia of Philosophy (Spring 2020). Metaphysics Research Lab, Stanford University. https://plato.stanford.edu/archives/spr2020/entries/al-kindi/

[5] Alfonso X king of Castile and Leon. (n.d.). Encyclopedia Britannica. Retrieved 21 July 2020, from

https://www.britannica.com/biography/Alfonso-X

[6] Al-Hakam II Collects a Vast Library at Cordoba in Al-Andalus: History of Information. (n.d.). Retrieved 21 July 2020, from http://www.historyofinformation.com/detail.php?id=214

[7] Al-Jawhari-Biography. (n.d.). Maths History. Retrieved 19 July 2020, from https://mathshistory.st-andrews.ac.uk/Biographies/AlJawhari/

[8] Anastassios-Fivos Christidis-A History of Ancient Greek_From the Beginnings to Late Antiquity-Cambridge University Press (2007).pdf. (n.d.).

[9] Baker, M., \& Saldanha, G. (Eds.). (2009). Routledge encyclopedia of translation studies (2nd ed). Routledge.

[10] Bsoul, L. A. (2019). Translation Movement and Acculturation in the Medieval Islamic World. Springer International Publishing. https://doi.org/10.1007/978-3-030-21703-7

[11] Fazlıoğlu et al. - 2007-Ishāq ibn Ḥunayn Abū Yạ̧qūb Ishāa ibn Ḥunayn (Eds.), The Biographical Encyclopedia of Astronomers (pp. 578-578). Springer New York. https://doi.org/10.1007/978-0-387-30400-7_704

[12] Hogendijk, J. P. (n.d.). The Introduction to Geometry by QusĐā ibn Lūqā: Translation and Commentary. 59.

[13] Hosam El-Din, M. (n.d.). Tarik al-Tarjamah al-Arabiya. Atida. Retrieved 18 July 2020, from

http://www.atida.org/forums/showthread.php?t=11421

[14] Hunayn ibn Ishaq-Biography. (n.d.). Maths History. Retrieved 19 July 2020, from https://mathshistory.standrews.ac.uk/Biographies/Hunayn/

[15] Lagerlund, H. (Ed.). (2011). Encyclopedia of Medieval Philosophy. Springer Netherlands. https://doi.org/10.1007/978-1-4020-9729-4

[16] Munday, J. (2016). Introducing translation studies: Theories and applications (Fourth edition). Routledge.

[17] Pym, A. (1994). Twelfth-Century Toledo and Strategies of the Literalist Trojan Horse. Target, 6(1), 43-66.

https://doi.org/10.1075/target.6.1.04pym

[18] Rosenthal, F. (2005). The classical heritage in Islam. Taylor \& Francis e-Library. http://www.myilibrary.com?id=15659

[19] Shikha, J. (2019, September 15). Dawr Madrasat al-Tarajamah bi Tolaytila fi Naql al-Aluloum al-Arabiya wa bi-ttali fi Nahdat Urubba (1/2). Rabitat Ulama Surya. Retrieved 21 July 2020, from https://islamsyria.com/site/show_articles/13124.

[20] The Greek Language-(A.-F.) Christidis A History of Ancient Greek. From the Beginnings to Late Antiquity. Pp. Xlii +1617 , ills, maps, Cambridge: Cambridge University Press, 2007.

[21] thorndike1959-John of Seville.pdf. (n.d.).

[22] Translation definition and meaning. Collins English Dictionary. (n.d.). Retrieved 16 July 2020, from https://www.collinsdictionary.com/dictionary/english/translation

[23] Turjuman. (n.d.). Al- Raid Dictionary. Retrieved 16 July 2020, from https://www.almaany.com/ar/dict/ar-ar/

[24] Turjuman. (n.d.). Lisan al-Arab Dictionay. Retrieved 16 July 2020, from https://www.almaany.com/ar/dict/ar-ar/

[25] Williams et al. (2007) - Ḥajjāj ibn Yūsuf ibn Mațar. In T. Hockey,Hajjāj ibn Yūsuf ibn Mațar.pdf. (Eds.), The Biographical Encyclopedia of Astronomers (pp. 460-461). Springer New York. https://doi.org/10.1007/978-0-387-30400-7_569

[26] Yamamoto et al. (2007). Qusțā ibn Lūqā al-Baçlabakkī. In T. Hockey, V. Trimble, T. R. Williams, K. Bracher, R. A. Jarrell, J. D. Marché, F. J. Ragep, J. Palmeri, \& M. Bolt (Eds.), The Biographical Encyclopedia of Astronomers (pp. 948-949). Springer New York.

https://doi.org/10.1007/978-0-387-30400-7_1138

[27] Yehuda ben Moshe-Wikiwand. (n.d.). Retrieved 1 September 2020, from https://www.wikiwand.com/en/Yehuda_ben_Moshe 